Correction

\title{
Correction: López-Prieto et al. Fungistatic and Fungicidal Capacity of a Biosurfactant Extract Obtained from Corn Steep Water. Foods 2020, 9, 662
}

\author{
Alejandro López-Prieto $^{1}\left(\mathbb{D}\right.$, Xanel Vecino ${ }^{2} \mathbb{D}$, Lorena Rodríguez-López $^{1} \mathbb{D}$, Ana Belén Moldes ${ }^{1, *(\mathbb{D})}$ \\ and José Manuel Cruz ${ }^{1}$ (D) \\ 1 Chemical Engineering Department, School of Industrial Engineering-Industrial and Technology Research \\ Centre (MTI), University of Vigo, Campus as Lagoas-Marcosende, 36310 Vigo, Spain; \\ alexlopez@uvigo.es (A.L.-P.); lorena@uvigo.es (L.R.-L.); jmcruz@uvigo.es (J.M.C.) \\ 2 Chemical Engineering Department, Polytechnic University of Catalunya (UPC)-Barcelona TECH, Barcelona \\ Research Center for Multiscale Science and Engineering, Campus Diagonal-Besòs, 08930 Barcelona, Spain; \\ xanel.vecino@upc.edu \\ * Correspondence: amoldes@uvigo.es
}

check for updates

Citation: López-Prieto, A.; Vecino, X.; Rodríguez-López, L.; Moldes, A.B.; Cruz, J.M. Correction: López-Prieto et al. Fungistatic and Fungicidal Capacity of a Biosurfactant Extract Obtained from Corn Steep Water. Foods 2020, 9, 662. Foods 2021, 10, 1318. https://doi.org/10.3390/foods 10061318

Received: 20 May 2021

Accepted: 3 June 2021

Published: 8 June 2021

Publisher's Note: MDPI stays neutral with regard to jurisdictional claims in published maps and institutional affiliations.

Copyright: (c) 2021 by the authors. Licensee MDPI, Basel, Switzerland. This article is an open access article distributed under the terms and conditions of the Creative Commons Attribution (CC BY) license (https:// creativecommons.org/licenses/by/ $4.0 /)$.
The authors would like to make the following correction to the published paper [1] a few words should be corrected in the abstract, pages 7 and 9:

- In the Abstract, "bactericidal" should be "fungicidal".

- In the Abstract, "low or high temperatures" should be "low temperatures".

- In the Abstract, "(50\% of inhibition)" should be "(50\% of inhibition) at the highest concentration".

- On page 7 , in the sentence, "a fungicidal effect (82.5\% of growth inhibition) was achieved at a biosurfactant concentration of $0.33 \mathrm{mg} / \mathrm{mL}^{\prime}$, " $0.33 \mathrm{mg} / \mathrm{mL}^{\prime}$ should be replaced by “ $0.99 \mathrm{mg} / \mathrm{mL}$ ".

- On Page 9, "resulted in inhibitions of 50\% and $100 \%$ at $4{ }^{\circ} \mathrm{C}$ during an incubation period of 5 and 10 days" should be "resulted in inhibitions of $100 \%$ and $57 \%$ at $4{ }^{\circ} \mathrm{C}$ and $25^{\circ} \mathrm{C}$, during an incubation period of 5 and 11 days".

- On Page 9, "a 100\% inhibition effect on $A$ brasiliensis was achieved after 10 days" should be "a $50 \%$ inhibition effect on $A$. brasiliensis was achieved after 10 days".

- On Page 9 , "39.6 ${ }^{\circ} \mathrm{C}$ " should be " $40^{\circ} \mathrm{C}$ ".

○ On Page 9, , $8.4{ }^{\circ} \mathrm{C}$ " should be " $8.5^{\circ} \mathrm{C}$ ".

Figure 1 and Tables 2 and 4 in the published paper are not correct. Please see the correct versions as shown below. 
Table 2. Operational conditions used in this study, expressed as coded dimensionless and uncoded independent variables: concentration of the biosurfactant $\left(x_{1}\right)$, temperature $\left(x_{2}\right)$, and incubation time $\left(x_{3}\right)$; the results obtained for the dependent variables: $y_{1}$ (\% of growth inhibition of $A$. brasiliensis) and $y_{2}$ (\% of growth inhibition of $C$. albicans). ( -1 , minimum value of the variable within the range; 0 , central value of the variable within the range; 1 , maximum value of the variable within the range).

\begin{tabular}{|c|c|c|c|c|c|c|c|c|}
\hline \multirow[b]{2}{*}{ Exp } & \multicolumn{3}{|c|}{ Coded Independent Variable } & \multicolumn{3}{|c|}{ Uncoded Independent Variable } & \multicolumn{2}{|c|}{ Dependent Variable } \\
\hline & $x_{1}$ & $x_{2}$ & $x_{3}$ & $x_{1}(\mathrm{mg} / \mathrm{mL})$ & $x_{2}\left({ }^{\circ} \mathrm{C}\right)$ & $x_{3}$ (Days) & $y_{1}$ & $y_{2}$ \\
\hline 1 & 0 & -1 & -1 & 0.66 & 4 & 5 & 100.00 & 0.00 \\
\hline 2 & 0 & 1 & -1 & 0.66 & 40 & 5 & 31.71 & 62.55 \\
\hline 3 & 0 & -1 & 1 & 0.66 & 4 & 11 & 100.00 & 0.00 \\
\hline 4 & 0 & 1 & 1 & 0.66 & 40 & 11 & 26.91 & 49.95 \\
\hline 5 & -1 & -1 & 0 & 0.33 & 4 & 8 & 100.00 & 17.79 \\
\hline 6 & -1 & 1 & 0 & 0.33 & 40 & 8 & 18.88 & 40.89 \\
\hline 7 & 1 & -1 & 0 & 0.99 & 4 & 8 & 100.00 & 0.00 \\
\hline 8 & 1 & 1 & 0 & 0.99 & 40 & 8 & 82.52 & 76.33 \\
\hline 9 & -1 & 0 & -1 & 0.33 & 22 & 5 & 0.00 & 6.42 \\
\hline 10 & -1 & 0 & 1 & 0.33 & 22 & 11 & 0.00 & 0.00 \\
\hline 11 & 1 & 0 & -1 & 0.99 & 22 & 5 & 30.43 & 11.07 \\
\hline 12 & 1 & 0 & 1 & 0.99 & 22 & 11 & 67.87 & 0.00 \\
\hline 13 & 0 & 0 & 0 & 0.66 & 22 & 8 & 0.00 & 0.00 \\
\hline 14 & 0 & 0 & 0 & 0.66 & 22 & 8 & 0.00 & 0.00 \\
\hline 15 & 0 & 0 & 0 & 0.66 & 22 & 8 & 0.00 & 0.00 \\
\hline
\end{tabular}

Table 4. Fungicidal and fungistatic conditions of the biosurfactant extracted from the CSW against $A$. brasiliensis and C. albicans in refrigerator storage $\left(4^{\circ} \mathrm{C}\right)$ and room temperature $\left(25^{\circ} \mathrm{C}\right)\left({ }^{*}\right.$ fungistatic effect, ${ }^{* *}$ fungicidal effect $)$.

\begin{tabular}{|c|c|c|c|c|c|c|}
\hline \multirow[b]{2}{*}{$\mathrm{T}\left({ }^{\circ} \mathrm{C}\right)$} & \multicolumn{3}{|c|}{ A. brasiliensis } & \multicolumn{3}{|c|}{ C. albicans } \\
\hline & $t$ (Days) & $\begin{array}{c}\text { Biosurfactant } \\
\text { Concentration }(\mathrm{mg} / \mathrm{mL})\end{array}$ & $\begin{array}{c}\text { Growth } \\
\text { Inhibition (\%) }\end{array}$ & $t$ (Days) & $\begin{array}{c}\text { Biosurfactant } \\
\text { Concentration }(\mathrm{mg} / \mathrm{mL})\end{array}$ & $\begin{array}{c}\text { Growth } \\
\text { Inhibition (\%) }\end{array}$ \\
\hline 4 & 5.0 & 0.33 & $100^{* *}$ & \multirow{2}{*}{5} & \multirow{2}{*}{0.99} & \multirow{2}{*}{17.9} \\
\hline 4 & 10.0 & 0.35 & $100^{* *}$ & & & \\
\hline 25 & 10.2 & 0.99 & $50^{*}$ & \multirow{2}{*}{5} & \multirow{2}{*}{0.99} & \multirow{2}{*}{20.0} \\
\hline 25 & 11.0 & 0.99 & $57^{*}$ & & & \\
\hline
\end{tabular}


a)

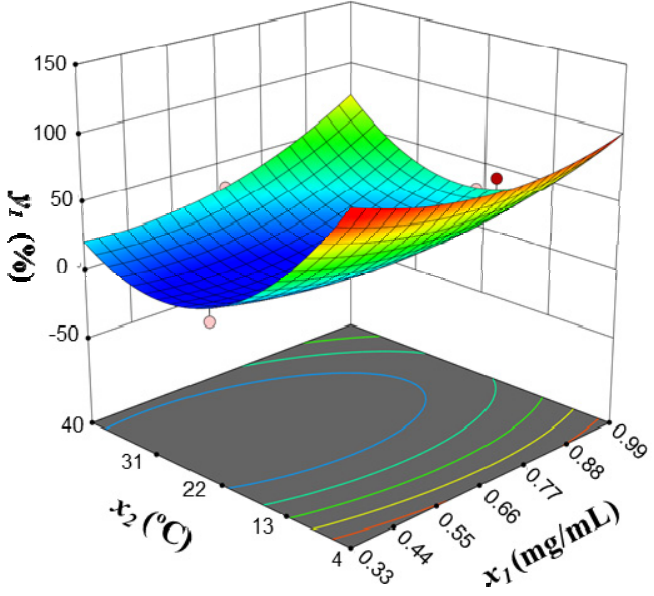

b)

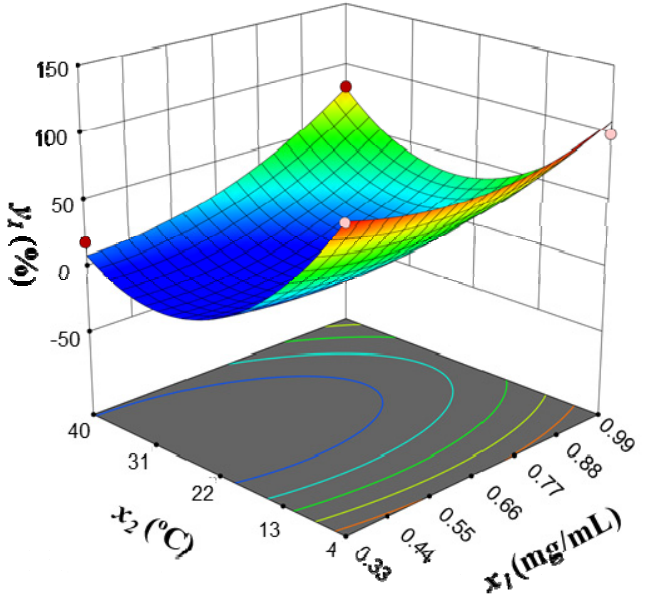

Growth Inhibition of A. brasiliensis (\%)

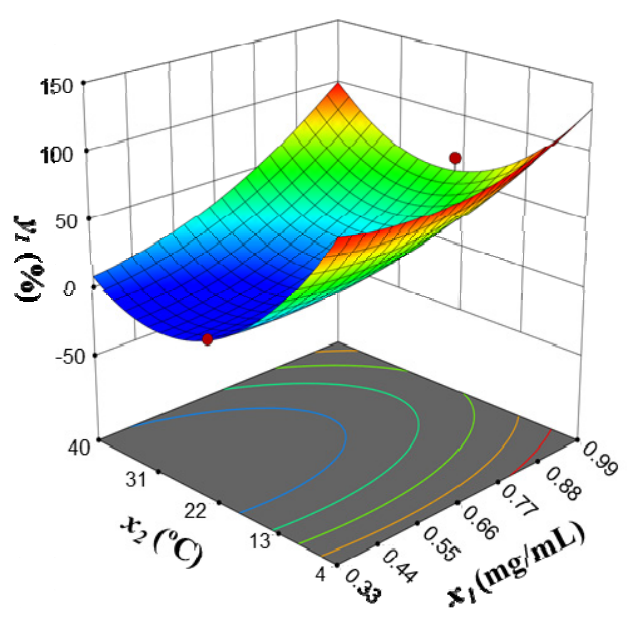

Design Points:

- Above Surtace

O Below Surface

Figure 1. Growth inhibition of A. brasiliensis (\%) as a function of the concentration of the biosurfactant $\left(x_{1}\right)$ and temperature $\left(x_{2}\right)$ of incubation for different incubation times $\left(x_{3}\right)$ : (a) 5 , (b) 8 and (c) 11 days.

The authors would like include a clarification in the manuscript regarding the fungicidal capacity of the biosurfactant extract under evaluation at $0.33 \mathrm{mg} / \mathrm{mL}$. This clarification is not the result of an error on the part of the journal:

A short explanation should be included in the Results and Discussion section after the discussion of Table 4 regarding the fungicidal capacity of $A$. brasiliensis: 
- "It was observed that the biosurfactant extract under evaluation showed a fungicidal capacity at low concentrations of biosurfactant, $0.33 \mathrm{mg} / \mathrm{mL}$, at $4{ }^{\circ} \mathrm{C}$ against $A$. brasiliensis. Therefore, it could be stated that this biosurfactant extract possesses good fungicidal properties to be used as a preservative in foods storage under refrigeration conditions".

The Foods Editorial Office would like to apologize for any inconvenience caused to the readers by these changes. The changes do not affect the scientific results. The published version will be updated on the article webpage, with a reference to this Correction.

\section{Reference}

1. López-Prieto, A.; Vecino, X.; Rodríguez-López, L.; Moldes, A.B.; Cruz, J.M. Fungistatic and Fungicidal Capacity of a Biosurfactant Extract Obtained from Corn Steep Water. Foods 2020, 9, 662. [CrossRef] [PubMed] 